\title{
Eating timing an evolutionary manager of postmodern rumen physiology and health: a review
}

This article was published in the following Dove Press journal:

Open Access Animal Physiology

7 October 2011

Number of times this article has been viewed

\section{Akbar Nikkhah}

Department of Animal Sciences, Faculty of Agricultural Sciences, University of Zanjan, Zanjan, Iran
Correspondence: Akbar Nikkhah Department of Animal Sciences, Faculty of Agricultural Sciences, University of Zanjan, Zanjan 313-45|95, Iran

$\mathrm{Tel}+9824|5| 5280$ I

Fax +98 24I 5283202

Email nikkhah@znu.ac.ir
Abstract: Natural diurnal patterns of grazing and rumination lead intensive ruminant production. Ruminants have evolved to ruminate mostly overnight and to graze during the day, especially during sunrise, the afternoon, and sunset. Accordingly, rumen fermentation, postrumen nutrient assimilation, and peripheral metabolism possess circadian patterns. The evolutionary patterns of eating behavior and metabolism have coexisted with seasonal and circadian rhythms in animal endocrinology. Such evolutionary natural eating, ruminating, and rumen fermentation patterns have been facing remarkable improvements in milk and beef production in the last few decades. As a result, new adaptations in ruminant endocrinology and metabolism have occurred. For optimum nutrient use and rumen health, a balanced synchrony between external cues and ruminant internal physiology may be secured. Most recent discoveries suggest that in addition to feed type and amount consumed, eating timing affects postprandial intake and rumen fermentation patterns. Findings of grazing and intensively managed cows are consistent. A main discovery has been an increased eating rate in lactating dairy cows when mixed rations were presented in the evening instead of in the morning. Consequently, evening eating increased rumen volume and fermentation as well as peripheral nutrient supply shortly after feeding. New findings reveal and establish a chronoecological nature for physical and biochemical regulation of feed intake and rumen fermentation. Such quantitative insights can improve the accuracy of rumen metabolism predictions. Eating time will therefore be incorporated into postmodern nutritional programs to ensure optimal rumen function and health. Eating time will be an interface of ruminant evolution, rumen ecology, and modern ruminant farming.

Keywords: eating timing, evolution, health, nutrition, physiology, rumen

\section{Introduction}

Ruminant metabolism is orchestrated homeostatically by shorter-term regulators such as volatile fatty acids (VFAs) and ammonia, and homeorhetically by longer-term regulators such as hormones and adipose tissue. These regulators enable ruminants to cope with different environmental and metabolic stressors during growth, estrus, pregnancy, and lactation. ${ }^{1,2}$ Based on recent findings, ${ }^{3-6}$ ruminant and rumen physiology has a chronoecological nature that relates to external cues and notably to feeding and eating times. Diurnal patterns of nutrient intake and rumen fermentation are not affected only by feed type and amount eaten. A most important factor that alters diurnal patterns of rumen physiology is the time of the 24-hour period when feed is presented to and ingested by the ruminant (Figure 1$).{ }^{6}$ Although improving efficiency, modern animal agriculture has challenged the sustainability of ruminant industries mainly by compromising rumen microbial fermentation and health. The challenge stems mainly 


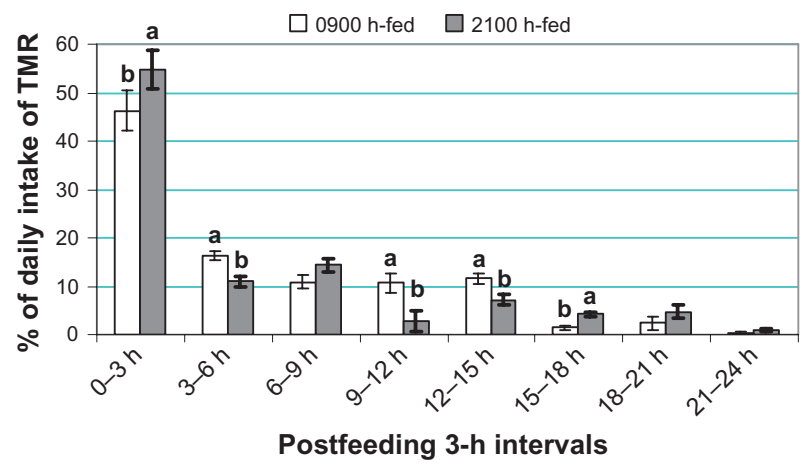

Figure I Postfeeding patterns of total mixed ration (TMR) intake in cows fed either at 09:00 or at 21:00. Bars with different superscripts within each 3-hour interval differ statistically. 4,6

from mismanaged feeding of high-starch, protein-rich, and fatty diets. The primary objective is to delineate the effects of time of eating on 24-hour patterns of rumen physiology and health. Diurnal and postfeeding patterns of feed intake in response to feeding time will also be discussed. This information will contribute to the development and advancement of optimal management and nutritional strategies that can improve postmodern rumen function and health.

\section{Synchronizing external cues with ruminant internal physiology}

From a chronophysiological perspective, for maximum peripheral efficiency, reticulorumen and splanchnic nutrient supply may be synchronized with animal endogenous physiological rhythms. Such rhythms represent the 24-hour variations in animal endocrinology and metabolism that are not largely food dependent. Endogenous rhythms are orchestrated by biological clocks in the hypothalamus ${ }^{7}$ and metabolic clocks in the liver and likely peripheral tissues. ${ }^{8}$ The suprachiasmatic nucleus (SCN) of the hypothalamus, for instance, creates and leads specialized metabolic rhythms that are highly adjusted to the light-dark cycle. ${ }^{8}$ The SCN coordinates many daily rhythms in animal behavior and physiology. The SCN has two bilateral groups of neurons and is located directly above the optical chiasma. The $\mathrm{SCN}$ neurons receive light intensity signals via synaptic connections with the retina, thereby adapting the SCN oscillator phase to photoperiod. ${ }^{8}$ The SCN clock then entrains physiological and behavioral rhythms. Feeding time as a major external cue entrains peripheral metabolism, which can be necessarily and largely independent of SCN. ${ }^{8}$ It is metabolically and economically important to reveal whether external cues such as feeding and eating times alter postfeeding patterns of food ingestion and rumen fermentation. Such knowledge will enable accurate predictions of diurnal patterns of rumen, postrumen, and peripheral nutrient supply and assimilation. As a result, times of the 24-hour period at which feed and nutrient supply will more likely improve rumen fermentation and nutrient assimilation will be uncovered. Multiple variables including rumen $\mathrm{pH}$, osmolarity, passage kinetics, VFA production rate, and their interactions affect nutrient efficiency. ${ }^{9}$ As such, rumen bacteria and protozoa populations, distribution, and activity would possess specialized diurnal patterns. Ruminant diets are usually more fibrous than nonruminant diets. For reliable feed intake and rumen health predictions, numerous rumen and postrumen variables must be accurately quantified. ${ }^{10}$ Thus, dietary and animal variables that affect diurnal and postprandial patterns of feed intake may be modified to alter postprandial patterns of rumen physiology and health.

Rumen concentrations of VFA are critical regulators of appetite. ${ }^{11,12}$ Portal propionate injection reduced dry matter intake in sheep. ${ }^{13}$ Propionate rather than acetate is likely to cause hypophagia. ${ }^{14}$ Insulin secretion ${ }^{15}$ and hepatic receptors ${ }^{11}$ mediate the hypophagic effects of propionate. Hepatic thermoreceptors may also control feed intake. For instance, heating the rat liver artificially increased chewing activity and reduced feed intake. ${ }^{16}$ These data emphasize the importance of characterizing and synchronizing feeding/ eating time effects with the ruminant internal circadian physiology to more effectively optimize nutrient efficiency, rumen health, and ruminant production.

\section{Eating time and modern ruminant evolution}

The lactating cow is an extraordinary mammal with high levels of feed intake and milk outputs (ie, as high as $6 \times$ maintenance). ${ }^{5,10}$ Rumen functionality and health drive the sustainable milk production. Any chronobiological mediation of rumen and intermediary metabolism will thus affect milk secretion and tissue energy dynamics. Ruminants have evolved to graze mainly around dusk, early afternoon, and dawn (Figure 2). ${ }^{17}$ As such, rumination takes place mostly between major eating bouts that mainly occur overnight when the rumen achieves greater fermentation capacity and volume. ${ }^{6,18}$ Eating during evening times when the ruminant has evolved to start to more actively ruminate can alter postfeeding fermentation patterns. In humans, for instance, glucose tolerance and insulin sensitivity decrease as the day progresses and evening begins. ${ }^{19}$ Considering the much greater energy intake above maintenance in dairy cows compared with in humans, the eating time-driven metabolic changes could considerably affect milk production and energy partitioning. 


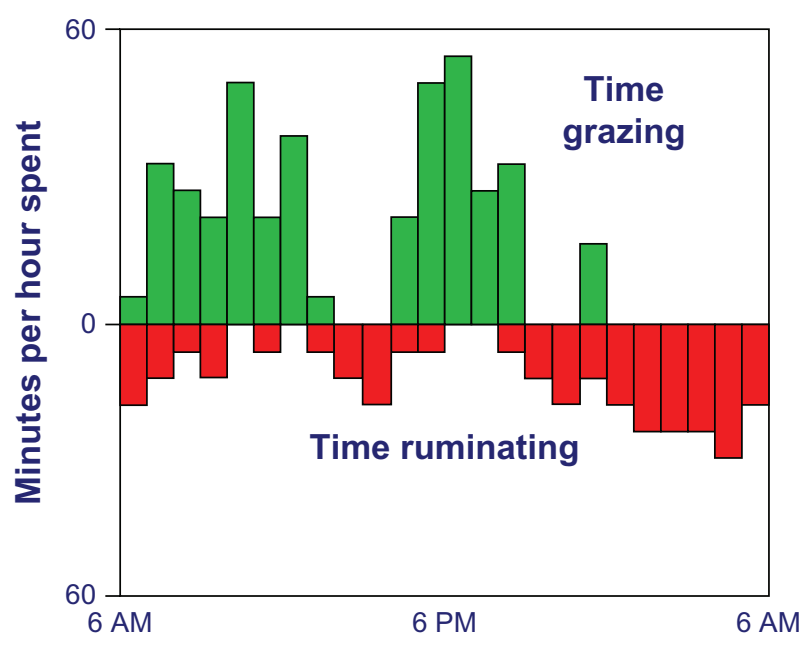

Figure 2 Diurnal patterns of ruminating and grazing in steers on alfalfa pastures.

Such eating time effects on postfeeding patterns of feed intake and rumen fermentation have recently been revealed in once-daily-fed (morning-fed vs evening-fed) lactating cows under normal ambient temperatures (Figure 1). ${ }^{3-6,20}$ When lactating cows were fed $67 \%$ of their daily mixed ration at 08:00 and $33 \%$ of it at 18:00, feeding a protein supplement (at $15 \%$ of estimated total daily intake) at 00:30 instead of at 08:30 increased the intake of the protein meal. ${ }^{21}$ As a result, total daily dry matter intake was increased $(16.92 \mathrm{~kg} / \mathrm{d}$ vs $15.94 \mathrm{~kg} / \mathrm{d}$ ), which was associated with increased rumen nutrient and protein digestibility. ${ }^{21}$ Midnight instead of morning protein meal eating thus altered and likely helped stabilize rumen fermentation. The improved rumen conditions were reflected in increased milk fat yield when the protein supplement was offered and consumed at midnight. ${ }^{21}$

Under hot and freezing conditions, evening instead of morning eating improved energy efficiency in dairy cows ${ }^{22}$ and beef cattle. ${ }^{23-25}$ The improved efficiency was related to reduced daily food intake under summer conditions. ${ }^{22,26}$ Overall, under such extreme ambient temperatures, separating the chronological effect of eating time from the effect of attenuated heat/cold stress on rumen and ruminant metabolism would be very challenging. Certainly, evening eating in the summer may benefit rumen and host animal thermodynamics. Most recent discoveries in normal environments have revealed such original eating timing effects on rumen fermentation patterns in once-daily-fed lactating dairy cows. ${ }^{5,6}$

\section{Evidence from grazing ruminants: meal properties}

Taweel et al ${ }^{18}$ divided the day into three main periods of (1) 06:00 to $12: 00$, (2) $12: 00$ to $18: 00$, and (3) $18: 00$ to $24: 00$.
The periods correspond to the three main grazing bouts of dawn, afternoon, and dusk in cows. ${ }^{27,28}$ Cows had access to a 1 hectare grass sward with continuous stocking. Rumen was evacuated at 06:00, 12:00, 18:00, and 23:30 to estimate food intake, bite rate, bite mass, and intake rate at the three grazing bouts. Time spent eating at the dusk grazing bout was much longer than that at the other two bouts. The dusk grazing comprised $40 \%$ of total daily eating time. Total grazing jaw movement rate was constant during the day at around 75 per minute. ${ }^{18}$ Bite rate, bite mass, and, hence, intake rate was increased while chewing rate was decreased as the day progressed. The increased bite mass was mainly due to increased grass dry matter content at dusk rather than to increased bite dimensions. Dairy cows interrupted the dawn and afternoon grazing bouts long before reaching their maximal rumen capacity. Rumen pool sizes were maximal when the dusk grazing ceased. Such different rumen pool responses to grazing time were substantiated by increased rumen VFA levels and lower $\mathrm{pH}$ overnight than during the day. ${ }^{18}$ Likewise, evening instead of morning eating led to higher rumen VFA and lower $\mathrm{pH}$ in nongrazing individually fed lactating cows indoors (Figure 3). A higher surge in peripheral blood $\beta$-hydroxybutyrate in evening-fed intensively managed cows would be consistent with the higher night-time rumen butyrate concentrations in grazing cows. Findings from grazing and intensive production systems are therefore in agreement. These data demonstrate a chronological evolutionary nature for the 24-hour patterns of eating behavior, rumen fermentation, and peripheral metabolism. The higher rumen VFA was a result of increased rumen dry matter and total tract fiber digestibility. As a result, milk fat production was increased in evening- and midnight-fed cows. ${ }^{5,6,21}$ Milk fat and energy output were increased when a total mixed ration was fed at 21:00 instead of at 09:00. 5,6

The eating/grazing activity has circadian patterns. With cows grazing at 09:00 after an overnight lack of access to feed/pasture, the postgrazing rumen dry matter pool size was much larger in the evening than the next morning. ${ }^{29}$ This means that cows ceased morning eating before reaching the maximum rumen capacity. Similarly, Taweel et al ${ }^{18}$ found that during dawn and afternoon grazing bouts, cows finished eating before reaching a rumen capacity that was reached during the dusk bout. Hence, effects of rumen fill on regulation of eating are of different magnitude in dusk versus dawn and afternoon intakes. Eating time effects on the 24-hour patterns of feed intake in nongrazing cows are summarized in Figure 1. 

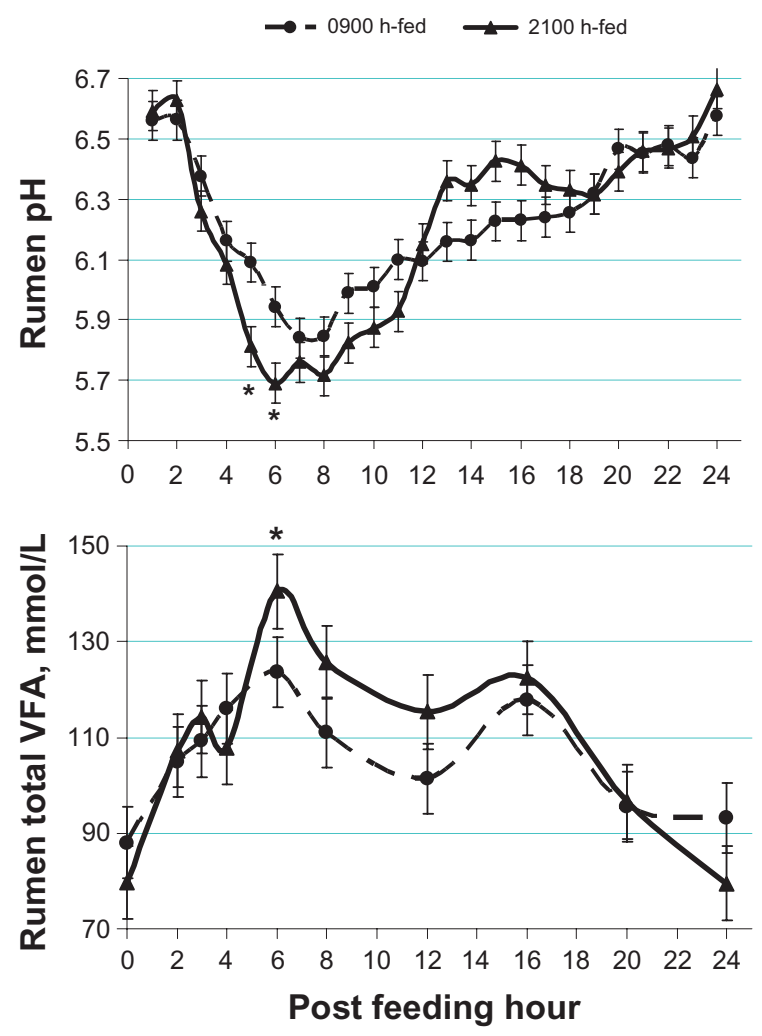

Figure 3 Postfeeding patterns of rumen $\mathrm{pH}$ (top) and total volatile fatty acids (VFA) concentrations (bottom) in cows fed either at 09:00 or at 21:00.

Note: $* P<0.05$ (within each hour)..$^{6,46}$

Enlarged evening meals in grazing cows could be considered an optimal foraging strategy. ${ }^{18,30,31}$ The plant contents of nonstructural carbohydrates and dry matter increase and neutral detergent fiber decreases as the day progresses. ${ }^{31,32}$ Such changes in plant nutrient composition occur because of daylight photosynthesis in plant leaves. ${ }^{33}$ This may partly explain why cattle, sheep, and goats prefer fresh grass and legume forages harvested at sunset rather than at sunrise. ${ }^{34,35}$ In vitro true digestibility of dry matter was greater in evening-cut than in morning-cut alfalfa hay. ${ }^{32}$ Lactating cows fed on eveningcut alfalfa performed superior to cows fed on morning-cut alfalfa with more stabilized rumen conditions and greater milk yield. ${ }^{36}$ Moreover, goats had greater feed intake and total tract nutrient digestibility when fed sunset-cut versus sunrise-cut alfalfa. Grazing ruminants likely evolve to learn the time of maximum plant quality, contributing to faster eating (mass per time unit) in evening versus morning hours. ${ }^{18}$

\section{Photoperiod and rumen nutritional physiology}

The eating rate of concentrate and hay in ad libitumfed goats was higher during dark versus light periods. ${ }^{37}$ Factors regulating feed intake may be of different type and magnitude in dark versus light periods. A nocturnal appetite for concentrate has been observed in goats. Also, a greater water intake was found around light-phase meals than around dark-phase meals in pygmy goats. ${ }^{38}$ As such, factors affecting feed and water intake are of unequal type and magnitude between day and night. Cows exhibit a nocturnal preference for energy-dense grass silage and concentrate. ${ }^{39}$ Findings suggest that short-term feed intake regulation mechanisms differ during the day versus the night. It is possible that as day progresses, cows demand more nutrients and attempt to consume adequate energy. ${ }^{40}$ Turning lights on and off may also induce eating activity, implying that animals may anticipate light turn-on-and-off times. Eating rate was highest around 05:00 and 21:00 when lights were switched on and off, respectively. ${ }^{41}$

The higher evening than morning eating rate could be an interactive response to several factors, rather than being solely related to light intensity. The anticipation of a noneating/resting phase (ie, overnight) could motivate animals to fill the rumen to avoid hunger later in the night. Moreover, the quieter environment and the higher herbage quality in the evening versus the morning may have evolutionarily contributed to increased evening eating rate. ${ }^{42,43}$ Furthermore, the rumen fill is only one of multiple factors regulating feed intake. ${ }^{42}$ As was recently revealed, ${ }^{5,6}$ the higher eating rate and increased feed intake within 3 hours postfeeding in 21:00-fed than in 09:00-fed tie stall-housed Holstein cows demonstrate that feeding/eating time is a key regulator of postfeeding patterns of nutrient intake and rumen physiology (Figures 1 and 3). Timing of eating will thus need to be incorporated into modern nutritional and health programs and feed evaluation models for ruminants..$^{44,45}$

As discussed previously, cows can learn the time of feed provision. Such a learning behavior could lead to cows anticipating feed presentation times with different accuracies at different times of the 24-hour period. ${ }^{45,46}$ Accordingly, if cows more accurately anticipate a given feed presentation, they will crave the fresh feed that will increase eating rate upon feed delivery. The altered feeding behavior will alter postprandial rumen fermentation patterns and thus can be used to manipulate and optimize rumen health.

\section{Integration of brain, splanchnic, and peripheral circadian physiology: eating timing-entrained phenomena}

Life is characterized by its circadian nature. Internal clocks give rise to circadian rhythms to enable animals and humans to cope with their circadian environments. Clock genes and 
their oscillation have created evolutionary and temporary circadian rhythms in cell physiology. The circadian core oscillators include autoregulatory transcription and posttranslation feedback loops involving a set of clock genes. ${ }^{47}$ The oscillation at gene level is reflected at cell, tissue, and system levels. The gene transcriptions reflect behavioral rhythms that include feeding behaviors. Therefore, clock gene oscillations are generated and controlled via the core loops in SCN neurons. The oscillations are subsequently joined, augmented, and spread into the whole brain and the periphery that contains local clocks. ${ }^{47}$ Consequently, behavioral and hormonal rhythms develop that further contribute to regulating nutrient metabolism at different times of the 24-hour period.

Food-anticipatory activity (FAN) is a premeal behavioral activation that involves a rise in core temperature, elevated serum corticosterone, and increased duodenal disaccharidases and locomotor activity shortly before food presentation time. ${ }^{48-50}$ Evidence exists that restricted feeding during the day uncouples peripheral circadian gene expression from the circadian SCN gene expression in mice..$^{51}$ The food-entrained phase proceeded faster in the liver than in the kidney, heart, and pancreas..$^{51}$ However, after 1 week of daytime feeding, gene expression phases were similar in all peripheral tissues. These findings suggest that FAN is driven by a circadian oscillator that could be essentially and mostly independent of SCN. ${ }^{52}$ Basically, FAN is rather regulated by multifaceted eating- and light-entrainable oscillators and memory. ${ }^{50} \mathrm{~A}$ likelihood has arisen that FAN is induced by a feeding-entrained oscillator that is located in the gastrointestinal tract. ${ }^{52}$ However, such entraining peripheral clocks have not been definitively demonstrated in the liver and digestive tract. Davidson et $\mathrm{a}^{52}$ suggested that the brain may have endogenous rhythmic aptitude within the central nervous system and outside the SCN. Despite discovering multiple food-entrainable circadian clocks in the brain and periphery, locating the clocks that are possibly responsible for FAN has been elusive. A recent study ${ }^{53}$ on SCN-lesioned mutant mice lacking known functioning circadian clocks in all tissues showed normal FAN during both the light-dark cycle and constant darkness, regardless of the position of the disabled clock feedback mechanism. This study suggested that FAN is not necessarily dependent on the already known circadian clocks. Thus, FAN is either not induced by an oscillator or is driven by a circadian entity that is different from the already recognized circadian clocks. ${ }^{53}$ The food-entrainable behavioral activity has also been demonstrated in sheep. ${ }^{54}$ Altogether, an integrative multifarious system involving the brain (central nervous system and $\mathrm{SCN}$ ), splanchnic tissue (liver, gut, spleen, pancreas, and associated tissue), and periphery will be central to any pathway whereby eating timing may entrain human and animal physiology in coping with the environment. Far more clock gene expression studies will need to be conducted to enlighten any entrainment of behavior and metabolism and cell, organ, and whole-body physiology by food and eating timing in animals and humans. Such mechanistic knowledge will clarify and establish "eating timing" as a major synchronizer of cell integrity and dynamics. Consequently, eating time will be perfectly distinguished as a state-of-the-art zeitgeber from photic (eg, light-dark period) and other nonphotic (eg, exercise, social stimuli, temperature) entrainers.

\section{Conclusion and implications}

Dependence of postfeeding intake patterns on eating timing is central to 24-hour and postfeeding patterns of rumen fermentation and health. Feeding lactating cows at 21:00 versus 09:00 in thermoneutral conditions has increased eating rate, thereby increasing feed intake by $2.5 \mathrm{~kg}$ within only 3 hours after feeding. Accordingly, evening instead of morning eating resulted in a larger rumen volume and increased rumen fermentation and, consequently, in increased total tract nutrient digestibility, peripheral substrate supply, and milk energy output. Findings of grazing and intensively managed cows on rumen chronophysiology are consistent. For optimum nutrient use and rumen function, external cues and ruminant endogenous physiology may be synchronized. New findings have revealed and established a chronoecological nature for regulation of feed intake and rumen fermentation. An integrative multifarious system involving brain, splanchnic, and peripheral tissues will be central to the pathways whereby eating timing entrains cell, organ, and whole-body physiology in coping with the environment. Quantitative knowledge on eating time modulation of rumen physiology will improve the accuracy of feed intake and rumen metabolism predictions. Eating time incorporation into modern ruminant management will help approach optimal rumen function. Eating time will be a postmodern interface of ruminant evolution, rumen physiology and health, and modern ruminant farming.

\section{Acknowledgment}

The Ministry of Science, Research and Technology and the University of Zanjan, Iran, are acknowledged for supporting the author's programs of optimizing science education in the third millennium. 


\section{Disclosure}

The author reports no conflicts of interest in this work.

\section{References}

1. Bauman DE. Regulation of nutrient partitioning during lactation: homeostasis and homeorhesis revisited. In: Cronje PB, editor. Ruminant physiology. Wallingford, UK: CABI Publishing; 2000:311-328.

2. Bauman DE, Currie WB. Partitioning of nutrients during pregnancy and lactation: a review of mechanisms involving homeostasis and homeorhesis. J Dairy Sci. 1980;63:1514-1546.

3. Nikkhah A, Plaizier JC, Furedi CJ, Kennedy AD. Response in diurnal variation of circulating blood metabolites to nocturnal vs diurnal provision of fresh feed in lactating cows. J Anim Sci. 2006;84(Suppl 1):111.

4. Nikkhah A, Plaizier JC, Furedi CJ, Kennedy AD. Time of feeding: a determinant of post feeding patterns in feed intake of lactating cows. J Dairy Sci. 2007;90(Suppl 1):559.

5. Nikkhah A, Furedi CJ, Kennedy AD, et al. Effects of feed delivery time on feed intake, rumen fermentation, blood metabolites and productivity of lactating cows. J Dairy Sci. 2008;91:1-12.

6. Nikkhah A, Furedi CJ, Kennedy AD, et al. Feed delivery at $2100 \mathrm{~h}$ vs $0900 \mathrm{~h}$ for lactating dairy cows. Can J Anim Sci. 2011;91:113-122.

7. la Fleur SE, Kalsbeek A, Wortel J, et al. Role for the pineal and melatonin in glucose homeostasis: pinealectomy increases night-time glucose concentrations. J Neuroendocrinol. 2001;13:1025-1032.

8. Sehgal A. Molecular Biology of Circadian Rhythms. Hoboken, NJ: John Wiley \& Sons, Inc; 2004.

9. Forbes JM. Voluntary Food Intake and Diet Selection in Farm Animals. Wallingford, UK: CABI Int.; 1995.

10. Van Soest PJ. Nutritional Ecology of the Ruminant. 2nd ed. Ithaca, NY: Cornell University Press; 1994.

11. Anil MH, Forbes JM. Feeding in sheep during intraportal infusions of short-chain fatty acids and the effect of liver denervation. J Physiol. 1980;298:407-414.

12. de Jong A, Steffens AB, de Ruiter L. Effects of portal volatile fatty acids infusions on meal patterns and blood composition in goats. Physiol Behav. 1981;27:683-689.

13. Farningham DAH, Whyte CC. The role of propionate and acetate in the control of food intake in sheep. Brit J Nutr. 1993;70:37-46.

14. Allen MS. Effects of diet on short-term regulation of feed intake by lactating dairy cattle. J Dairy Sci. 2000;83:1598-1624.

15. Grovum WL. Mechanisms explaining the effects of short chain fatty acids on feed intake in ruminants-osmotic pressure, insulin and glucagon. In: v Englehardt W, Leonhard-Marek S, Breves G, Geisecke D, editors. Ruminant Physiology: Digestion, Metabolism, Growth and Reproduction, Stuttgart, Germany: Ferdinand Enke Verlag; 1995:173-197.

16. Di Bella L, Tarozzi G, Rossi MT, Scalera G. Effect of liver temperature increase on food intake. Physiol Behav. 1981;6:45-51.

17. Rook AJ, Huckle CA. Activity bout criteria for grazing dairy cows. Appl Anim Behav Sci. 1997;54:89-96.

18. Taweel HZ, Tas BM, Dijkstra J, Tamminga S. Intake regulation and grazing behavior of dairy cows under continuous stocking. J Dairy Sci. 2004;87:3417-3427.

19. la Fleur SE. Daily rhythms in glucose metabolism: suprachiasmatic nucleus output to peripheral tissue. J Neuroendocrinol. 2003; 15:315-322.

20. Nikkhah A. Postprandial rhythms of circulating urea in lactating dairy cows: feeding timing and diet effects. Biol Rhythm Res. 2011. In press.

21. Robinson PH, Gill M, Kennelly JJ. Influence of time of feeding a protein meal on ruminal fermentation and forestomach digestion in dairy cows. J Dairy Sci. 1997;80:1366-1373.

22. Aharoni Y, Brosh A, Harari Y. Night feeding for high-yielding dairy cows in hot weather: effects on intake, milk yield and energy expenditure. Livest Prod Sci. 2005;92:207-219.
23. Kennedy AD, Bergen RD, Lawson TJ, et al. Effects of evening feeding and extended photoperiod on growth, feed efficiency, live animal carcass traits and plasma prolactin of beef heifers housed outdoors during two Manitoba winters. Can J Anim Sci. 2004;84:491-500.

24. Schwartzkopf-Genswein KS, Beauchemin KA, McAllister TA, et al. Effect of feed delivery fluctuations and feeding time on ruminal acidosis, growth performance, and feeding behavior of feedlot cattle. J Anim Sci. 2004;82:3357-3365.

25. Small JA, Kennedy AD, Veira DM, et al. Time of feeding and growth promotant effects on the winter growth performance and carcass traits of steers. Can J Anim Sci. 2004;84:133-144.

26. Ominski KH, Kennedy AD, Wittenberg KM, Moshtaghi Nia SA. Physiological and production responses to feeding schedule in lactating dairy cows exposed to short-term, moderate heat stress. J Dairy Sci. 2002;85:730-737.

27. Arnold GW. Composition of the time budgets and circadian patterns of maintenance activities in sheep, cattle and horses grouped together. Appl Anim Behav Sci. 1984;13:19-30.

28. Rook AJ, Huckle CA. Synchronization of ingestive behaviour by grazing dairy cows. Anim Sci. 1997;60:25-30.

29. Chilibroste P, Tamminga S, Boer H. Effects of length of grazing session, rumen fill and starvation time before grazing on dry matter intake, ingestive behaviour and dry matter rumen pool sizes of grazing lactating dairy cows. Grass Forage Sci. 1997;52:249-257.

30. Penning PD, Parsons AJ, Orr RJ, et al. Intake and behaviour responses by sheep, in different physiological states, when grazing monocultures of grass or white clover. Appl Anim Behav Sci. 1991;45:63-78.

31. Taweel HZ, Tas BM, Smit HJ, et al. A note on eating behaviour of dairy cows at different stocking systems-diurnal rhythm and effects of ambient temperature. Appl Anim Behav Sci. 2006;98:315-322.

32. Burns JC, Mayland HF, Fisher DS. Dry matter intake and digestion of alfalfa harvested at sunset and sunrise. J Anim Sci. 2005;83:262-270.

33. Delagarde R, Peyraud JL, Delaby L, Faverdin P. Vertical distribution of biomass, chemical composition and pepsin-cellulase digestibility in a perennial ryegrass sward: interaction with month of year, regrowth age and time of day. Anim Feed Sci Technol. 2000;84:49-68.

34. Fisher DS, Mayland HF, Burns JC. Variation in ruminant preference for tall fescue hays cut at either sundown or sunup. J Anim Sci. 1999;77:762-768.

35. Fisher DS, Mayland HF, Burns JC. Variation in ruminant preference for alfalfa hays cut at sunup and sundown. Crop Sci. 2002;42: 231-237.

36. Brito F, Tremblay GF, Bertrand A, et al. Alfalfa cut at sundown and harvested as baleage improves milk yield of late-lactation dairy cows. J Dairy Sci. 2009;91:3968-3982.

37. Senn M, Langhans W, Scharrer E. Meal patterns of pygmy goats fed hay and concentrate ad lib. Physiol Behav. 1990;48:49-53.

38. Rossi R, Scharrer E. Circadian patterns of drinking and eating in Pygmy goats. Physiol Behav. 1992;51:895-897.

39. Dürsta B, Senna M, Langhans W. Eating patterns of lactating dairy cows of three different breeds fed grass ad lib. Physiol Behav. 1993;54:625-631.

40. Senn M, Dürst B, Kaufmann A, Langhans W. Feeding patterns of lactating cows of three different breeds fed hay, corn silage, and grass silage. Physiol Behav. 1995;58:229-236.

41. Feddes JJR, Young BA, DeShazer JA. Influence of temperature and light on feeding behaviour of pigs. Appl Anim Behav Sci. 1989;23:215-222.

42. Linnane MI, Brereton AJ, Giller PS. Seasonal changes in circadian grazing patterns of Kerry cows (Bos Taurus) in semi-feral conditions in Killarney National Park, Co. Kerry, Ireland. Appl Anim Behav Sci. 2001;71:277-292.

43. Provenza FD, Villalba JJ, Cheney CD, Werner SJ. Self-organization of foraging behaviour: from simplicity to complexity without goals. Nutr Res Rev. 1998;11:199-222.

44. NRC. National Research Council, nutrient requirements of dairy cattle. 7th rev ed. Washington, DC: National Acad Sci; 2001. 
45. Nikkhah A. Bioscience of ruminant feed intake evolution: feeding time models. Adv Biosci Biotechnol. 2011;2:271-274.

46. Nikkhah A. Ruminant chronophysiological management: an emerging bioscience. Open Access Animal Physiology. 2011;3:9-12.

47. Okamura $\mathrm{H}$. Integration of mammalian circadian clock signals: from molecule to behavior. $J$ Endocrinol. 2003;177:3-6.

48. Richter CP. A behavioristic study of the rat. Comp Psychol Mon. 1922;1:1-55.

49. Stephan FK. The "other" circadian system: food as a zeitgeber. J Biol Rhythms. 2002;17:284-292.

50. Mistlberger RE. Circadian food-anticipatory activity: Formal models and physiological mechanisms. Neurosci Biobehav Rev. 1994;18:171-195.
51. Damiola F, Le Minh N, Preitner N, et al. Restricted feeding uncouples circadian oscillators in peripheral tissues from the central pacemaker in the suprachiasmatic nucleus. Genes Dev. 2000;14:2950-2961.

52. Davidson AJ, Poole AS, Yamazaki S, Menaker M. Is the foodentrainable circadian oscillator in the digestive system? Genes Brain Behav. 2003;2:32-39.

53. Storch K-F, Weitz CJ. Daily rhythms of food-anticipatory behavioral activity do not require the known circadian clock. Proc Nat Acad Sci. 2009;106:6808-6813.

54. Piccione G, Bertolucci C, Caolaa G, Foa A. Effects of restricted feeding on circadian activity rhythms of sheep: a brief report. Appl Anim Behav Sci. 2007;107:233-238.

\section{Publish your work in this journal}

Open Access Animal Physiology is an international, peer-reviewed, open access journal publishing original research, reports, reviews and commentaries on all areas of animal physiology. The manuscript management system is completely online and includes a very

\section{Dovepress}

quick and fair peer-review system. Visit http://www.dovepress.com/ testimonials.php to read real quotes from published authors. 